\title{
SISTEM PENGELOLAAN SEBARAN DATA PRODUK DAN KLIEN DENGAN IMPLEMENTASI PETA ONLINE
}

\author{
Nur Alamsyah \\ Fakultas Ilmu Komputer Universitas Nasional PASIM \\ Jalan Dakota No 8a. Kota Bandung Jawa Barat 40175 Telepon (022) 6072803 \\ nuralamsyah.bdg@gmail.com
}

\begin{abstract}
Abstrak
Penelitian perancangan perangkat lunak ini bertujuan untuk membantu mengelola data produk dan data klien di PT. USSI Bandung - Jawa Barat. Penelitian ini merupakan dampak dari semakin pesatnya teknologi yang mengakibatkan beberapa pekerjaan dapat di handle atau dibantu oleh teknologi tersebut. Terlebih lagi dengan adanya komputer dimana hal tersebut semakin meningkatkan efisiensi dan kualitas dalam bekerja. Dengan adanya komputer, manusia diberi kemudahan-kemudahan dalam menyelesaikan pekerjaan diberbagai bidang, misalnya pengelolaan data produk dan klien yang menggunakan aplikasi pencatatan produk dan klien berbasis web. Dalam penerapannya, teknologi komputer ini bisa menyimpan data yang cepat dan tepat serta juga dapat menampilkan data tersebut secara detail dan lebih informatif. Alhasil dari semua itu informasi data klien akan tercatat secara optimal dan lebih informatif. Tugas ini juga diharapkan mampu memberikan informasi segala hal yang berhubungan dengan produk maupun klien dari mulai development produk, implementasi produk, launching produk, dsb.
\end{abstract}

Kata Kunci : sistem komputer, produk klien, pencatatan data.

\begin{abstract}
The research design of software aims to help managing data products and data clients in PT .Ussi Bandung - West Java. This research is the impact of the advance of technology resulting in some works to handle or it is assisted by the technology. Moreover by the computer, it improves efficiency and quality in work. By the use of computer, people will be easy in finishing the job in various fields for example the management of product data and client that use web based application recording product and client. In practice, computer technology could save the data quickly and correctly and also it displays the data in detail and more informative. As a result, all information clients will be recorded optimally and more informative. This research is also expected to provide information about all matters relating to clients products or starting development products, the implementation of products, launching products, etc.
\end{abstract}

Keywords : A computer system, products clients, recording the data

\section{PENDAHULUAN}

1.1 Latar Belakang

Sistem informasi dan teknologi telah menjadi komponen yang sangat penting bagi keberhasilan bisnis dan organisasi. Teknologi informasi, memainkan peranan penting dan makin luas dalam bisnis. Teknologi informasi dapat membantu segala jenis bisnis meningkatakan efisiensi dan efektivitas proses bisnis perusahaan, pengambilan keputusan manajerial, dan kerja sama kelompok kerja, hingga dapat memperkuat posisi kompetitif mereka 
dalam pasar yang cepat sekali berubah. Dengan adanya sistem informasi, dapat melakukan berbagai aktivitas sehingga pekerjaan menjadi mudah dan waktu yang cepat. Pada era saat ini sistem informasi sangat bermanfaat dalam bidang dunia kerja, dimana sistem informasi itu sendiri memiliki peranan penting dalam kehidupan manusia seperti menjalankan pekerjaan di tempat kerja dengan hasil pekerjaan yang cepat dan akurat untuk mempercepat dan mempermudah proses pekerjaan.

Dalam proses bisnis yang membutuhkan kecepatan, transparansi dan akunbilitas dalam proses pada suatu sistem Enterprise terutama memberikan pelayanan prima (Excellenct Service) yang dapat memenuhi dan memuaskan palanggan serta memberikan fokus pelayanan kepada pelanggan maka perlukannya suatu sistem informasi dan teknologi.

\subsection{Identifikasi Masalah}

Berdasarkan latar belakang masalah yang telah diuraikan diatas, dapat diidentifikasikan masalah-masalah seperti berikut :

1. Pengelolaan data klien dan produk masih menggunakan aplikasi google spreedsheet sehingga kurang efisien dalam pengelolaan data dan dari sisi fitur pun terbatas, diperlukan suatu database dan sistem baru untuk mengganti sistem yang ada secara keseluruhan dengan membuat aplikasi lain yang lebih akurat dan informatif untuk mengoptimalkan data produk dan klien.

2. Data klien yang sudah menggunakan produk-produk dari divisi R\&D Digital Financial Services belum terorganisir dengan baik, padahal data tersebut berpengaruh kepada portofolio perusahaan yang menjadi daya tarik perusahaan terhadap klien.

\subsection{Pembatasan Masalah}

Untuk menghindari meluasnya permasalahan yang ada, maka batasan masalah yang dibuat yaitu :

1. Sistem ini akan digunakan untuk pengolaan pencatatan daftar produk dan daftar klien yang hanya meliputi proses penginputan daftar klien dan daftar produk.

2. Menampilkan informasi daftar klien yang akan ditampilkan pada peta dengan menggunakan maps dari google serta melihat produk apa saja yang telah digunakan oleh klien tersebut.

\section{METODOLOGI PENELITIAN}

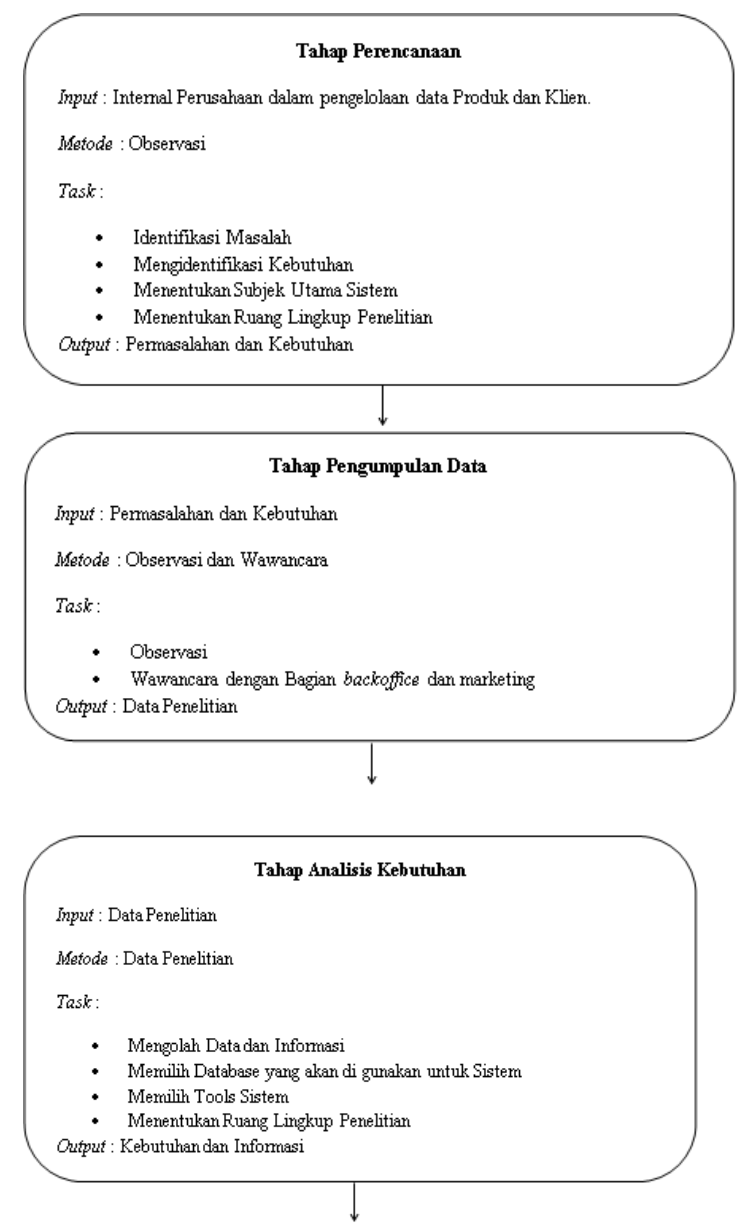




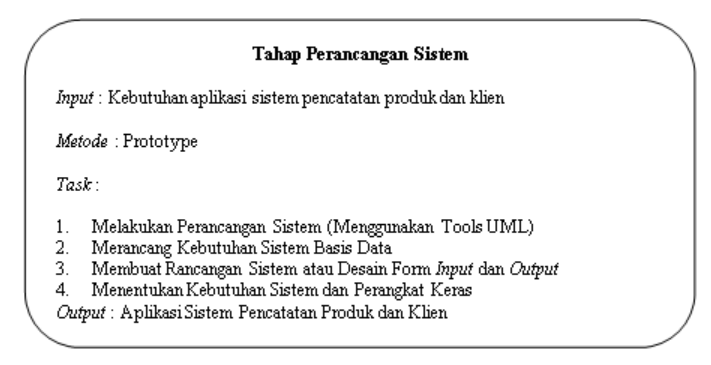

\section{Penjelasan Diagram Metode Penelitian}

Berikut ini penjelasan dari Diagram Metode Penelitian

\section{Tahap Perancanaan}

Input: BackOffice dan Marketing perusahaan kesulitan dalam pengelolaan data perpusahaan baik dalam pencatatan produk-produk maupun klien-klien yang sudah bekerjasama dengan perusahaan

Metode: Dalam tahap perencanaan ini dengan cara wawancara kepada bagian marketing dan backoffice.

Task: Berdasarkan hasil wawancara yang telah dilakukan maka terdapat permasalahan sebagai berikut :

a. Pencatatan data produk dan klien masih menggunakan google spreedshet

b. Membutuhkan aplikasi yang dapat membantu pencatatan lebih efisien dan efektif yang sistematis

c. Kesulitan dalam melakukan proses pencarian data yang di butuhkan

d. Ingin memunculkan tampilan lokasi alamat klien dengan Maps

e. Belum menghasilkan tampilan data yang cepat, tepat, akurat dan lebih informatif

f. Dapat di gunakan untuk tools tim marketing dalam menyampaikan portofolio perusahaan

Output: Berdasarkan hasil dari tahap perencanaan ini dapat diketahui permasalahannya yaitu belum tersedianya aplikasi pencatatan produk dan klien, data masih menggunakan google spreedshet yang dengan fitur seadanya, belum menghasilkan informasi data yang lebih informatif,cepat dan akurat, dan belum bisa digunakan oleh tim marketing dalam mempresentasikan portofolio perusahaan.

\section{Tahap Pengumpulan Data}

Input: Berdasarkan hasil tahapan perencanaan diatas dapat diketahui permasalahan yaitu belum tersedianya aplikasi, data masih menggunakan google spreedshet yang dengan fitur seadanya, belum menghasilkan informasi data yang lebih informatif,cepat dan akurat, dan belum bisa digunakan oleh tim marketing dalam mempresentasikan portofolio perusahaan.

Metode: Dalam tahap pengumpulan data ini metode yang digunakan yaitu observasi dan wawancara.

Task: Untuk pengumpulan data dengan metode observasi dilakukan dengan cara berinteraksi langsung dengan permasalahan yang ada pada perusahaan yang bersangkutan dan dengan metode wawancara dilakukan dengan mewawancarai bagian Backoffice dan Marketing.

Ouput: Berdasarkan hasil tahap pengumpulan data ini maka dapat disimpulkan data penelitiannya meliputi data Produk, data Klien, Maps Lokasi Klien dan data klien yang sudah menggunakan produk apa saja.

\section{Tahap Analisis Kebutuhan}

Input: Berdasarkan output yang dihasilkan dari tahap pengumpulan data diatas dalam tahap analisis kebutuhan inputnya data Produk, data Klien, Maps Lokasi Klien dan data klien yang sudah menggunakan produk apa saja.

Metode: Dalam tahap analisis kebutuhan ini untuk merancang Aplikasi Sistem Pencatatan Produk dan 
Klien Digital menggunakan database MySQL dan PHP sebagai bahasa pemogramannya, adapun ruang lingkup dalam tahap analisis kebutuhan ini yaitu merancang sistem web.

Output: Hasil dari tahap ini dibutuhkan Pendekatan $O O P$ yang mempunyai alat bantu (tool) yaitu UML(Unified Modeling Language). Model pengembangan sistem yang digunakan yaitu model pengembangan prototype. serta membuat Struktur Tabel, Relasi Antar Tabel, Struktur Menu, dan Rancangan Input Output.

\section{Tahap Perancangan Aplikasi Sistem Pencatatan Produk dan Klien}

Input : Kebutuhan dan Informasi

Metode : Prototype

Task :

1. Use Case Diagram

2. Rancangan Skenario

3. Activity Diagram

4. Class Diagram

5. Sequence Diagram

6. Struktur Tabel

7. Struktur Menu

8. Rancangan Input dan Output.

Output : Hasil dari tahapan perancangan ini adalah model sistem pencatatan produk dan klien yang berbasis digital

\section{PEMBAHASAN}

\section{Pemodelan Use Case Sistem}

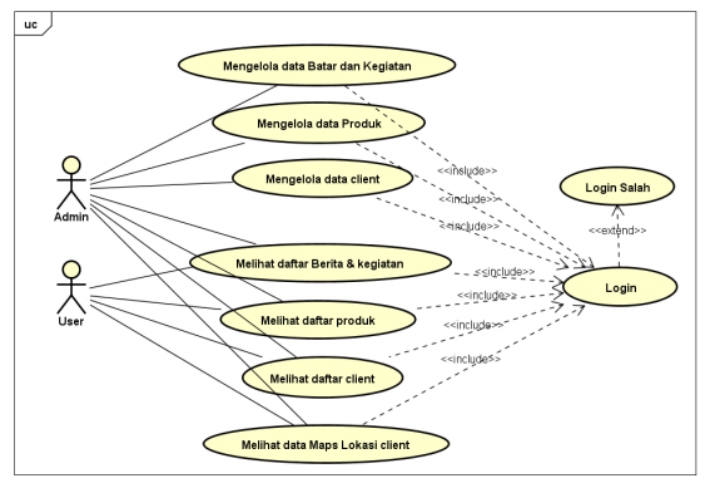

Use Case Produk dan Klien
User Case yang terlibat pada pengelolaan data produk dan klien berdasarkan penggunaannya antara lain sebagai berikut :

a. Use Case Login

b. Use Case Menampilkan Data Produk dan Klien

c. Use Case Menampilkan Berita \& Kegiatan

d. Use Case Mengelola Posting Berita \& Kegiatan

e. Use Case Mengelola Data Product

f. Use Case Mengelola Data Klien

g. Use Case Menampilkan Maps Lokasi Klien

\section{Scenario Use Case}

Skenario Use Case merupakan tabel yang mendeskripsikan rincian dari tiap use case. Berikut ini scenario use case untuk setiap use case yang ada pada aplikasi sistem pencatatan produk dan klien yang akan dibangun, yaitu :

\begin{tabular}{|c|c|}
\hline \multicolumn{2}{|c|}{ Skenario Login } \\
\hline \multicolumn{2}{|l|}{ Nomor: UCS-01 } \\
\hline \multicolumn{2}{|l|}{ Nama : UseCase Login } \\
\hline \multicolumn{2}{|c|}{ Deskripsi : Meng-input username dan password } \\
\hline \multicolumn{2}{|l|}{ Aktor : Admin dan User } \\
\hline \multicolumn{2}{|c|}{ Kondisi Awal : Admin memasuki halaman Form Login } \\
\hline \multicolumn{2}{|l|}{ Skenario } \\
\hline Aksi Aktor & Reaksi Sistem \\
\hline $\begin{array}{l}\text { 1. Masuk ke Form Login. } \\
\text { 3. Input username dan } \\
\text { password. }\end{array}$ & $\begin{array}{l}\text { 1. Menampilkan } \\
\text { Form Login. } \\
\text { 2. Validasi Username } \\
\text { \& Password. } \\
\text { 3. 5. Masuk ke Form } \\
\text { Menu } \\
\text { Utama/Dashboard. }\end{array}$ \\
\hline \multicolumn{2}{|l|}{ Exceptional Case } \\
\hline Username \& Password inv & mbali ke Form Login \\
\hline
\end{tabular}


JURNAL NUANSA INFORMATIKA

Volume 13 Nomor 1, Januari 2019

Skenario Mendampilkan Data Produk dan Klien

\begin{tabular}{|c|c|}
\hline \multicolumn{2}{|l|}{ Nomor: UCS-02 } \\
\hline \multicolumn{2}{|c|}{$\begin{array}{l}\text { Nama : UseCase Menampilkan Informasi Data Produk dan } \\
\text { Klien }\end{array}$} \\
\hline \multicolumn{2}{|c|}{ Deskripsi : Melihat data Produk dan Klien } \\
\hline \multicolumn{2}{|l|}{ Aktor : Admin dan Users } \\
\hline \multicolumn{2}{|c|}{ Kondisi Awal : Admin memasuki halaman Dashboard } \\
\hline \multicolumn{2}{|l|}{ Skenario } \\
\hline Aksi Aktor & Reaksi Sistem \\
\hline $\begin{array}{l}\text { 1. Masuk ke Menu } \\
\text { Dashboatd. } \\
\text { 2.Pilih dan klik gambar } \\
\text { Marker lokasi klien. }\end{array}$ & $\begin{array}{l}\text { 1. Menampilkan Maps } \\
\text { Lokasi Pengguna. } \\
\text { 2. Menampilkan } \\
\text { Informasi lengkap } \\
\text { klien. } \\
\text { 3. Menampilkan Daftar } \\
\text { Produk yang digunakan } \\
\text { klien tersebut. }\end{array}$ \\
\hline \multicolumn{2}{|l|}{ Exceptional Case } \\
\hline - & \\
\hline
\end{tabular}

Menampilkan Data Berita \& Kegiatan

\begin{tabular}{|c|c|}
\hline \multicolumn{2}{|l|}{ Nomor: UCS-03 } \\
\hline \multicolumn{2}{|c|}{ Nama : UseCase Menampilkan Berita \& Kegiatan } \\
\hline \multicolumn{2}{|c|}{ Deskripsi : Melihat Berita \& Kegiatan } \\
\hline \multicolumn{2}{|l|}{ Aktor : Admin dan User } \\
\hline \multicolumn{2}{|c|}{$\begin{array}{l}\text { Kondisi Awal : Admin memasuki halaman Berita \& } \\
\text { Kegiatan }\end{array}$} \\
\hline \multicolumn{2}{|l|}{ Skenario } \\
\hline Aksi Aktor & Reaksi Sistem \\
\hline $\begin{array}{l}\text { 1. Masuk ke Menu Berita \& } \\
\text { Kegiatan. } \\
\text { 3. Klik Baca Selengkapnya. }\end{array}$ & $\begin{array}{l}\text { 1. Menampilkan Beita \& } \\
\text { Kegiatan. } \\
\text { 2. Aplikasi Men-direct } \\
\text { ke website sumber } \\
\text { berita tersebut }\end{array}$ \\
\hline Exceptional Case & \\
\hline
\end{tabular}

p-ISSN : 1858-3911, e-ISSN : 2614-5405

\section{Activity Diagram}

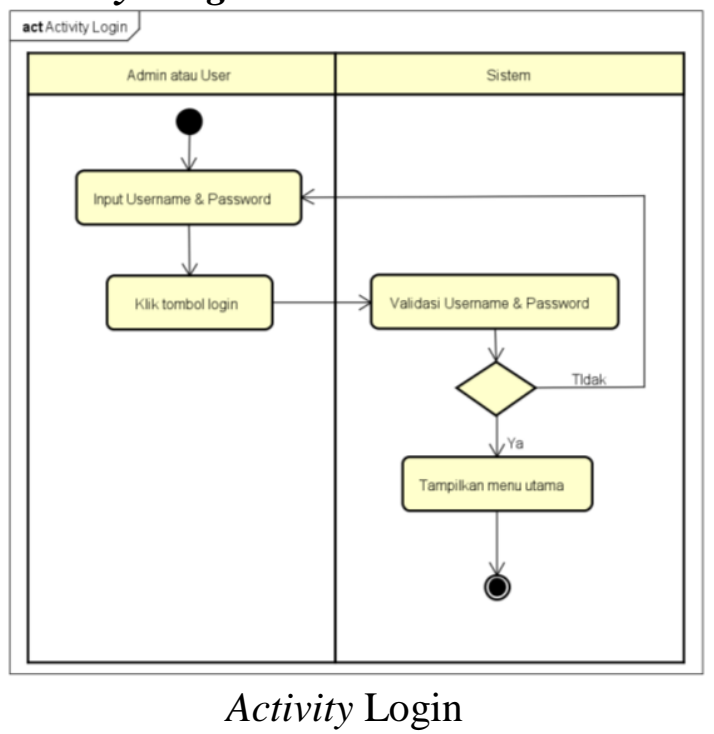

Kegiatan dari activity diagram di atas, sebagai berikut :

1. Admin atau User memasuki Form Login dan meng-input-kan nama pengguna dan kata sandi nya.

2. Setelah mengisi Form Login, Admin atau User meng-klik tombol Login untuk masuk ke Menu Utama.

3. Jika nama pengguna dan kata sandi salah, maka sistem akan menampilkan kotak pesan bahwa nama pengguna dan kata sandi tidak sesuai, dan akan menampilkan kembali Form Login.

4. Bila username dan password sudah sesuai, maka sistem akan menampilkan Form Menu Utama. 


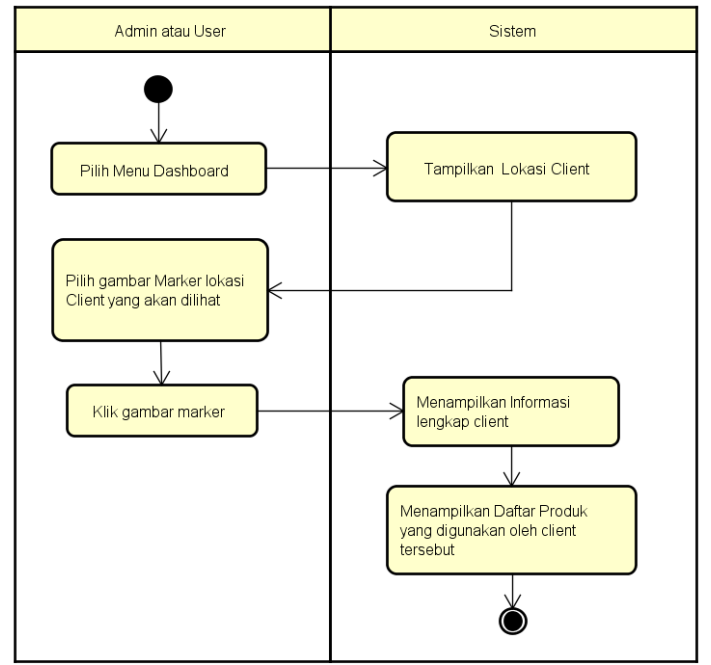

Activity View Produk dan Klien

Kegiatan dari activity diagram di atas, sebagai berikut :

1. Setelah Login valid, Admin atau User masuk ke Menu Utama aplikasi yaitu menu dashboard.

2. Sistem menampilkan Maps lokasi seluruh klien.

3. Admin atau User meng-klik gambar Marker klien pada Maps tersebut

4. Sistem akan menampilkan informasi data lengkap klien (Nama, Tipe Lembaga, Alamat, Alamat Detail, No Telepon)

5. Sistem akan menampilkan produk-produk apa saja yang telah digunakan oleh klien tersebut

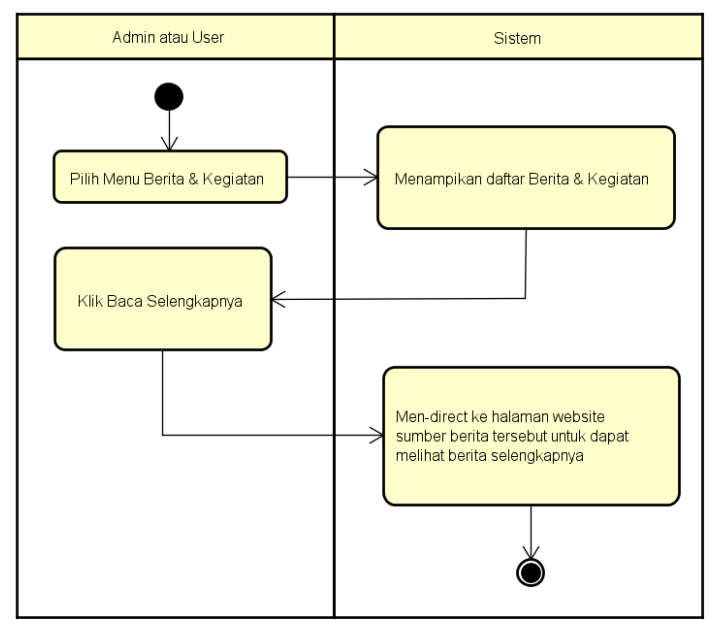

Activity View News
Kegiatan dari activity diagram di atas, sebagai berikut :

1. Setelah Login valid, Admin atau User masuk ke Menu Berita \& Kegiatan.

2. Sistem menampilkan daftar Berita $\&$ Kegiatan.

3. Admin atau User memilih berita yang dibaca dan mengklik Baca Selengkapnya

4. Sistem akan men-direct ke halaman website sumber berita tersebut untuk dapat melihat informasi dari berita tersebut secara lengkap

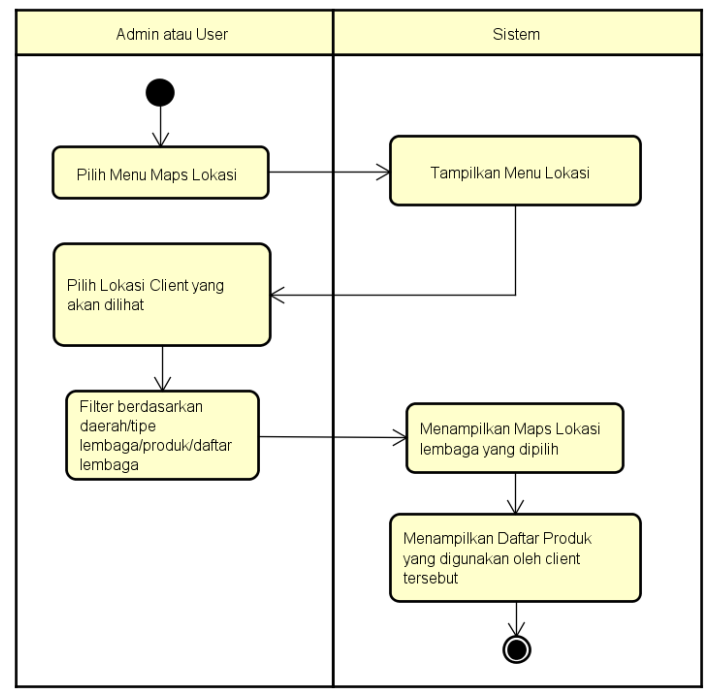

Activity View Maps Location

Kegiatan dari activity diagram di atas, sebagai berikut :

1. Setelah Login valid, Admin atau User masuk ke Menu Maps Lokasi.

2. Sistem menampilkan Maps lokasi.

3. Admin atau User memfilter dan memilih klien yang akan dilihat berdasarkan daerah atau tipe lembaga, produk ataupun langsung memilih pada list daftar lembaga.

4. Sistem akan menampilkan otomatis ke Maps Lokasi Klien yang di pilih serta menampilkan informasi data lengkap klien (Nama, Tipe Lembaga, Alamat, Alamat Detail, No Telepon).

5. Sistem akan menampilkan produkproduk apa saja yang telah digunakan oleh klien tersebut 


\section{Class Diagram}

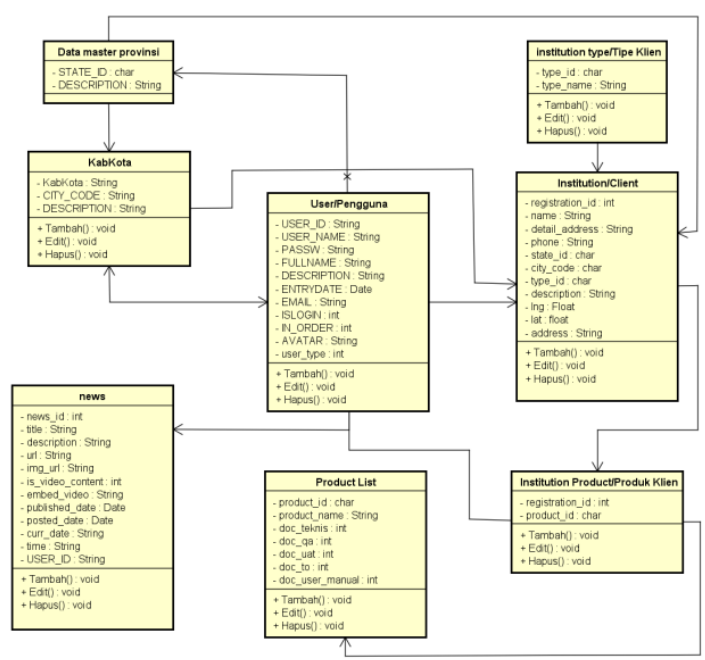

Class Diagram Produk dan Klien Implementasi

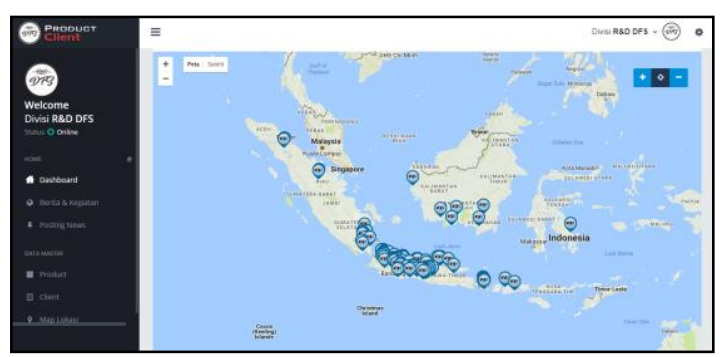

Implementasi Halaman

Utama/Dashboard

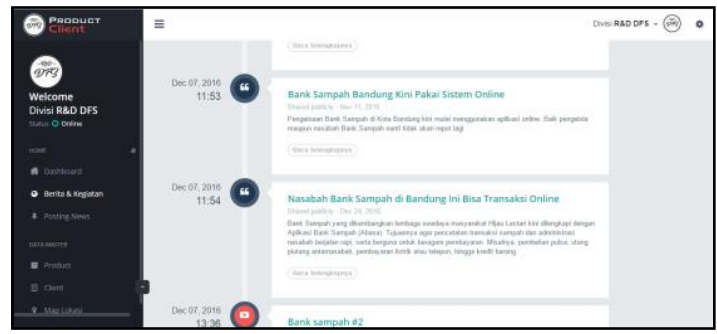

Implementasi Halaman Berita dan

Kegiatan

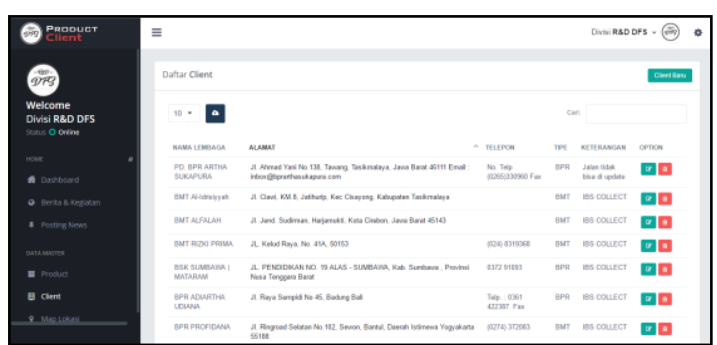

p-ISSN : 1858-3911, e-ISSN : 2614-5405

https://journal.uniku.ac.id/index.php/ilkom

\section{Pengujian Sistem}

Sebelum perangkat lunak diterapkan maka dilakukan pengujian terlebih dahulu terhadap perangkat untuk mengetahui apakah masih terdapat kesalahan-kesalahan kode program ataupun bugs didalamnya. Pengujian yang dilakukan menggunakan metode blackbox. Pengujian blackbox merupakan pengujian program berdasarkan fungsi program. Pengujian dilakukan dengan memberikan masukan (input) tertentu pada program aplikasi yang kemudian diproses sesuai dengan kebutuhannya dan dilihat apakah hasil akhir (output) yang dihasilkan sesuai dengan yang diinginkan. Apabila hasil akhir yang dilakukan sesuai dengan yang diharapkan maka program aplikasi tersebut telah benar, namun apabila menghasilkan hasil akhir yang belum sesuai, maka masih terdapat kesalahan didalamnya.

Tabel Pengujian Login

\begin{tabular}{|c|l|l|l|c|}
\hline No & $\begin{array}{c}\text { Skenario } \\
\text { Pengujian }\end{array}$ & $\begin{array}{l}\text { Hasil Yang } \\
\text { Diharapkan }\end{array}$ & $\begin{array}{l}\text { Hasil Yang } \\
\text { Didapatkan }\end{array}$ & $\begin{array}{l}\text { Kesim } \\
\text { pulan }\end{array}$ \\
\hline 1 & $\begin{array}{l}\text { Menginputkan } \\
\text { username dan } \\
\text { password } \\
\text { dengan benar, } \\
\text { lalu klik } \\
\text { tombol Login }\end{array}$ & $\begin{array}{l}\text { Sistem dapat } \\
\text { menerima } \\
\text { akses Login } \\
\text { dan } \\
\text { kemudian } \\
\text { masuk ke } \\
\text { halaman } \\
\text { utama }\end{array}$ & $\begin{array}{l}\text { Login } \\
\text { berhasil dan } \\
\text { masuk ke } \\
\text { halaman } \\
\text { utama }\end{array}$ & Valid \\
\hline 2 & $\begin{array}{l}\text { Mengosongkan } \\
\text { form } \\
\text { usernamedan } \\
\text { password lalu } \\
\text { klik tombol } \\
\text { Login }\end{array}$ & $\begin{array}{l}\text { Sistem akan } \\
\text { menolak } \\
\text { akses Login }\end{array}$ & $\begin{array}{l}\text { Login } \\
\text { ditolak dan } \\
\text { tetap berada } \\
\text { di menu }\end{array}$ & Valid \\
\hline 3 & $\begin{array}{l}\text { Menginputkan } \\
\text { username dan } \\
\text { password yang } \\
\text { tidak sesuai, } \\
\text { lalu klik Login }\end{array}$ & $\begin{array}{l}\text { Sistem akan } \\
\text { menolak } \\
\text { akses Login }\end{array}$ & $\begin{array}{l}\text { Login } \\
\text { ditolak dan } \\
\text { tetap berada } \\
\text { di menu }\end{array}$ & Valid \\
Login & \\
\hline
\end{tabular}


JURNAL NUANSA INFORMATIKA

Volume 13 Nomor 1, Januari 2019
p-ISSN : 1858-3911, e-ISSN : 2614-5405

https://journal.uniku.ac.id/index.php/ilkom
Pengujian Menu Produk

\begin{tabular}{|c|c|c|c|c|}
\hline No & $\begin{array}{c}\text { Skenario } \\
\text { Pengujian }\end{array}$ & $\begin{array}{l}\text { Hasil Yang } \\
\text { Diharapka } \\
\text { n }\end{array}$ & $\begin{array}{l}\text { Hasil Yang } \\
\text { Didapatkan }\end{array}$ & $\begin{array}{c}\text { Kesi } \\
\text { mpul } \\
\text { an }\end{array}$ \\
\hline 1 & $\begin{array}{l}\text { Tambah } \\
\text { data } \\
\text { produk } \\
\text { dengan } \\
\text { melengka } \\
\text { pi semua } \\
\text { form,lalu } \\
\text { klik } \\
\text { tombol } \\
\text { "Apply } \\
\text { Product" }\end{array}$ & $\begin{array}{l}\text { Sistem } \\
\text { sukses input } \\
\text { data produk }\end{array}$ & $\begin{array}{l}\text { Data produk } \\
\text { berhasil } \\
\text { tersimpan } \\
\text { dan muncul } \\
\text { keterangan } \\
\text { "1 Produk } \\
\text { baru berhasil } \\
\text { ditambahkan } \\
\text { " }\end{array}$ & Valid \\
\hline 2 & $\begin{array}{l}\text { Tambah } \\
\text { data } \\
\text { produk } \\
\text { dengan } \\
\text { tidak } \\
\text { melengka } \\
\text { pi semua } \\
\text { form,lalu } \\
\text { klik } \\
\text { tombol } \\
\text { "Apply } \\
\text { Product" }\end{array}$ & $\begin{array}{l}\text { Sistem tidak } \\
\text { dapat } \\
\text { memproses } \\
\text { data produk }\end{array}$ & $\begin{array}{l}\text { Data produk } \\
\text { tidak } \\
\text { tersimpan, } \\
\text { muncul } \\
\text { keterangan } \\
\text { pada salah } \\
\text { satu form } \\
\text { "This field is } \\
\text { required" }\end{array}$ & Valid \\
\hline 3 & $\begin{array}{l}\text { Sistem } \\
\text { dapat } \\
\text { melakuka } \\
\mathrm{n} \text { proses } \\
\text { edit Data } \\
\text { Produk } \\
\text { dengan } \\
\text { mengklik } \\
\text { tombol } \\
\text { berbentuk } \\
\text { pensil }\end{array}$ & $\begin{array}{l}\text { Sistem } \\
\text { dapat } \\
\text { menampilka } \\
\mathrm{n} \text { form edit, } \\
\text { lalu berhasil } \\
\text { memproses } \\
\text { data produk } \\
\text { yang telah } \\
\text { diubah }\end{array}$ & $\begin{array}{l}\text { Data produk } \\
\text { berhasil } \\
\text { diubah, } \\
\text { muncul } \\
\text { keterangan } \\
\text { "Data } \\
\text { berhasil } \\
\text { dirubah" }\end{array}$ & Valid \\
\hline 4 & $\begin{array}{l}\text { Sistem } \\
\text { dapat } \\
\text { melakuka } \\
\text { n proses } \\
\text { Delete } \\
\text { Data } \\
\text { Produk } \\
\text { dengan } \\
\text { mengklik } \\
\text { tombol } \\
\text { berbentuk } \\
\text { tong } \\
\text { sampah }\end{array}$ & $\begin{array}{l}\text { Sistem } \\
\text { dapat } \\
\text { menghapus } \\
\text { data produk } \\
\text { dan muncul } \\
\text { peringatan } \\
\text { terlebih } \\
\text { dahulu } \\
\text { sebelum } \\
\text { dihapus }\end{array}$ & $\begin{array}{l}\text { Data } \\
\text { berhasil } \\
\text { dihapus, } \\
\text { muncul } \\
\text { keterangan } \\
\text { "Delete } \\
\text { record } \\
\text { product?" } \\
\text { sebelum } \\
\text { dihapus dan } \\
\text { muncul } \\
\text { keterangan } \\
\text { "Data } \\
\text { berhasil } \\
\text { dihapus" } \\
\text { ketika data } \\
\text { dihapus }\end{array}$ & Valid \\
\hline
\end{tabular}

Pengujian Menu Klien

\begin{tabular}{|c|c|c|c|c|}
\hline $\begin{array}{l}\mathbf{N} \\
\mathbf{0}\end{array}$ & $\begin{array}{l}\text { Skenari } \\
\text { o } \\
\text { Penguji } \\
\text { an }\end{array}$ & $\begin{array}{l}\text { Hasil } \\
\text { Yang } \\
\text { Diharapk } \\
\text { an }\end{array}$ & $\begin{array}{l}\text { Hasil } \\
\text { Yang } \\
\text { Didapat } \\
\text { kan }\end{array}$ & $\begin{array}{l}\text { Kesimpu } \\
\text { lan }\end{array}$ \\
\hline 1 & $\begin{array}{l}\text { Tambah } \\
\text { data } \\
\text { klien } \\
\text { dengan } \\
\text { melengk } \\
\text { api } \\
\text { semua } \\
\text { form,lal } \\
\text { u klik } \\
\text { tombol } \\
\text { "Simpan } \\
\text { ", }\end{array}$ & $\begin{array}{l}\text { Sistem } \\
\text { sukses } \\
\text { input data } \\
\text { klien }\end{array}$ & $\begin{array}{l}\text { Data } \\
\text { klien } \\
\text { berhasil } \\
\text { tersimpan } \\
\text { dan } \\
\text { muncul } \\
\text { keteranga } \\
\text { n } \\
\text { "Tambah } \\
\text { data } \\
\text { lembaga } \\
\text { sukses" }\end{array}$ & Valid \\
\hline 2 & $\begin{array}{l}\text { Tambah } \\
\text { data } \\
\text { klien } \\
\text { dengan } \\
\text { tidak } \\
\text { melengk } \\
\text { api } \\
\text { semua } \\
\text { form,lal } \\
\text { u klik } \\
\text { tombol } \\
\text { "Simpan } \\
\text { „ }\end{array}$ & $\begin{array}{l}\text { Sistem } \\
\text { tidak } \\
\text { dapat } \\
\text { memprose } \\
\text { s data } \\
\text { klien }\end{array}$ & $\begin{array}{l}\text { Data } \\
\text { klien } \\
\text { tidak } \\
\text { tersimpan } \\
\text {, muncul } \\
\text { keteranga } \\
\text { n pada } \\
\text { beberapa } \\
\text { satu form } \\
\text { "This } \\
\text { field is } \\
\text { required" }\end{array}$ & Valid \\
\hline 3 & $\begin{array}{l}\text { Sistem } \\
\text { dapat } \\
\text { melakuk } \\
\text { an } \\
\text { proses } \\
\text { edit Data } \\
\text { Klien } \\
\text { dengan } \\
\text { mengkli } \\
\text { k tombol } \\
\text { berbentu } \\
\text { k pensil }\end{array}$ & $\begin{array}{l}\text { Sistem } \\
\text { dapat } \\
\text { menampil } \\
\text { kan form } \\
\text { edit, lalu } \\
\text { berhasil } \\
\text { memprose } \\
\text { s data } \\
\text { klien yang } \\
\text { telah } \\
\text { diubah }\end{array}$ & $\begin{array}{l}\text { Data } \\
\text { klien } \\
\text { berhasil } \\
\text { diubah, } \\
\text { muncul } \\
\text { keteranga } \\
\text { n "Ubah } \\
\text { data } \\
\text { Lembaga } \\
\text { sukses" }\end{array}$ & Valid \\
\hline 4 & $\begin{array}{l}\text { Sistem } \\
\text { dapat } \\
\text { melakuk } \\
\text { an } \\
\text { proses } \\
\text { Delete } \\
\text { Data } \\
\text { Klien } \\
\text { dengan } \\
\text { mengkli } \\
\text { k tombol } \\
\text { berbentu } \\
\text { k tong } \\
\text { sampah }\end{array}$ & $\begin{array}{l}\text { Sistem } \\
\text { dapat } \\
\text { menghapu } \\
\text { s data } \\
\text { klien dan } \\
\text { muncul } \\
\text { peringatan } \\
\text { terlebih } \\
\text { dahulu } \\
\text { sebelum } \\
\text { dihapus }\end{array}$ & $\begin{array}{l}\text { Data } \\
\text { berhasil } \\
\text { dihapus, } \\
\text { muncul } \\
\text { keteranga } \\
\text { n "Hapus } \\
\text { data } \\
\text { Client?" } \\
\text { sebelum } \\
\text { dihapus } \\
\text { dan } \\
\text { muncul } \\
\text { keteranga } \\
\text { n "Hapus } \\
\text { lembaga } \\
\text { sukses" } \\
\text { ketika } \\
\text { data } \\
\text { dihapus }\end{array}$ & Valid \\
\hline
\end{tabular}




\section{Kesimpulan Pengujian}

Berdasarkan hasil pengujian dengan kasus uji sample diatas dapat ditarik kesimpulan bahwa perangkat lunak bebas dari kesalahan sintaks dan secara fungsional mengeluarkan hasil yang sesuai dengan yang diharapkan.

\section{Kesimpulan dan Saran}

\subsection{Kesimpulan}

Berdasarkan dari data-data yang telah dikumpulkan pada penelitian yang berlangsung kemudian diolah, hasil pengolahan data-data tersebut dituangkan ke dalam laporan Skirpsi ini, maka kesimpulan yang dapat diambil sebagai berikut

Dari hasil penelitian yang telah dilakukan dengan menyelesaikan perancangan sebuah aplikasi bantu, maka permasalahan yang ada telah teratasi dengan kehadiran aplikasi bantu ini. Sehingga dapat diambil beberapa kesimpulan, diantaranya sebagai berikut

1. Sistem ini mampu menyimpan data secara sistemasi, tepat, dan akurat yang media penyimpanannya cukup besar serta dinamis dalam pengelolaan data dan lebih efektif dan efisien dalam pengelolaan pencatatan produk dan klien, sehingga kekeliruan dalam pencatatan dapat teratasi

2. Sistem ini mampu menampilkan data klien dan data produk secara detail dan sangat informatif sehingga data dapat teroganisir dengan baik.

\subsection{Saran}

Pada pembuatan aplikasi sistem pencatatan produk dan klien berbasis web di PT. USSI Bandung ini masih diperlukan pengembangan agar menjadi lebih sempurna serta sangat difungsikan kegunaannya. Penulis juga berharap alat bantu ini bisa di maintenance untuk pemakaian jangka panjang dan lebih terawat dalam pengoperasiannysa. Adapun saran yang diharapkan yaitu, pada pengembangan selanjutnya juga dibuatkan fitur untuk mencatat rekam keluhan klien, supaya klien yang membutuhkan supporting juga dapat ter-monitor melalui aplikasi ini.

\section{Daftar Pustaka}

Amsyah, Zulkifli., 1997. Manajemen Sistem Informasi. Penerbit Jakarta : PT. Gramedia.

Davis, Gordon B, Kerangka Dasar: Sistem Informasi Manajemen, Bagian I Pengantar. Seri Manajemen No. 90-A. Cetakan Kedua Belas, Jakarta: PT. Pustaka Binawan Pressindo, 2002.

George R. Terry, Ph.D (1962). Office Management and Control, Fourth Edition. Homewood, Ilinois: Richard D. Irwin Inc.

Hengky W. Pramana, (2006), Aplikasi Inventory Berbasis Access 2003, Elex Media Komputindo, Jakarta.

Roger S. Pressman, (2009), Rekayasa Perangkat Lunak, Yogyakarta Andi ; McGRaw-Hill Book co

Jogiyanto. 2001. Analisis \& Desain Sistem Informasi : pendekatan terstruktur teori dan praktek aplikasi bisnis. Andi, Yogyakarta.

Robert G Murdick, dkk, Sistem Informasi Untuk Manajemen 
JURNAL NUANSA INFORMATIKA

Volume 13 Nomor 1, Januari 2019
p-ISSN : 1858-3911, e-ISSN : 2614-5405

https://journal.uniku.ac.id/index.php/ilkom
Modern, Jakarta Penerbit Erlangga, 1991.

Santoso, Harip. (2010). Aplikasi Web/asp.net + cd. Jakarta : Elex Media Kompitindo.

Widianti, Sri, Pengantar Basis Data, Jakarta, Penerbit Fajar, 2000.
Sugiyono. "Metode Penelitian Kuantitatif Kualitatif Dan $R \& D ”$. Bandung: Alfabeta: 2013

Yuhefizar. (2008). 10 JAM menguasai Internet: Teknologi dan Aplikasinya. PT. Elex Media,Komputindo, Jakarta. 